their preference for one device over the other by splitting 100 points between them.

Results Participants perceived $\mathrm{BH}$ to be superior to RM on 20 of 22 and similar on 2 of 22 handling-related device attributes (Figure 1). Participants found $\mathrm{BH}$ more intuitive to use (69:31), easier to use $(60: 40)$ and offering higher confidence that the full dose has been taken $(58: 42)$. Finally, there was a preference for $\mathrm{BH}$ over RM (56:44).

Conclusions The consistently higher preference for $\mathrm{BH}$ regarding device handling-related attributes and its position as the preferred device suggest that it offers an opportunity for improved compliance and therefore improved control of COPD.
P288 COPD PATIENTS WITH VARYING SEVERITY OF AIRFLOW LIMITATION ACHIEVE HIGHEST PEAK INSPIRATORY FLOW RATE VIA THE BREEZHALER ${ }^{\circledR}$ INHALER COMPARED TO THE ELLIPTA ${ }^{\circledR}$ OR THE HANDIHALER ${ }^{\circledR}$ DRY POWDER INHALERS

${ }^{1} \mathrm{P}$ Goyal, ${ }^{2} \mathrm{~L}$ Wehbe, ${ }^{1} \mathrm{~J}$ Dederichs, ${ }^{3} \mathrm{~T}$ Guerin, ${ }^{1} \mathrm{MC}$ Moronta, ${ }^{4} \mathrm{AV}$ Pino, ${ }^{1} \mathrm{~K}$ Kostikas, ${ }^{5} \mathrm{p}$ Altman. 'Novartis Pharma AG, Basel, Switzerland; ' Instituto Ave Pulmo, Fundación Enfisema, Mar del Plata, Argentina; ${ }^{3}$ Novartis Ireland Limited, Dublin, Ireland; ${ }^{4}$ Novartis Argentina, S.A., Argentina; ${ }^{5}$ Novartis Pharmaceuticals Corporation, East Hanover, USA

\subsection{6/thoraxjnl-2016-209333.431}

Background and aim Chronic and progressive nature of COPD necessitates the patients to regularly self-administer inhaled medication. Inhalation effort required and flow rates achieved through DPIs, are some of the important considerations while selecting

Abstract P288 Table 1 Comparison of PIF rates (L/min) by COPD severity (per protocol set)

\begin{tabular}{|c|c|c|c|c|c|c|c|}
\hline $\begin{array}{c}\text { Inhalation } \\
\text { device }\end{array}$ & $\mathbf{n}$ & $\begin{array}{c}\text { PIF rate, Mean } \\
\text { (SE) }\end{array}$ & Comparison & $N^{*}$ & $\begin{array}{c}\text { Mean } \\
\text { difference }\end{array}$ & $95 \% \mathrm{Cl}$ & p-value \\
\hline \multicolumn{8}{|c|}{ Moderate COPD } \\
\hline \multirow{2}{*}{ Breezhaler $^{\circ}$} & \multirow{2}{*}{45} & \multirow{2}{*}{$108.3(3.81)$} & $\begin{array}{l}\text { Breezhaler }{ }^{\circ} \mathrm{vs} . \\
\text { Ellipta" }\end{array}$ & 41 & 28.9 & $(23.68,34.16)$ & $<0.0001$ \\
\hline & & & $\begin{array}{l}\text { Breezhaler"vs. } \\
\text { HandiHaler" }\end{array}$ & 45 & 57.5 & $(51.64,63.36)$ & $<0.0001$ \\
\hline Ellipta & 41 & $80.4(2.64)$ & $\begin{array}{l}\text { Ellipta"vs. } \\
\text { HandiHaler" }\end{array}$ & 41 & 29.4 & $(25.62,33.15)$ & $<0.0001$ \\
\hline HandiHaler ${ }^{\circ}$ & 45 & $50.8(1.78)$ & & & & & \\
\hline \multicolumn{8}{|l|}{ Severe COPD } \\
\hline \multirow{2}{*}{ Breezhaler ${ }^{\circ}$} & \multirow{2}{*}{38} & \multirow{2}{*}{$108.8(3.67)$} & $\begin{array}{l}\text { Breezhaler }{ }^{\circ} \text { vs. } \\
\text { Ellipta" }\end{array}$ & 37 & 26.2 & $(19.73,32.62)$ & $<0.0001$ \\
\hline & & & $\begin{array}{l}\text { Breezhaler"vs. } \\
\text { HandiHaler" }\end{array}$ & 38 & 51.3 & $(42.29,60.31)$ & $<0.0001$ \\
\hline Ellipta & 37 & $82.1(4.03)$ & $\begin{array}{l}\text { Ellipta"vs. } \\
\text { HandiHaler" }\end{array}$ & 37 & 24.5 & $(16.99,32.08)$ & $<0.0001$ \\
\hline HandiHaler ${ }^{\circ}$ & 38 & $57.5(4.66)$ & & & & & \\
\hline \multicolumn{8}{|c|}{ Very severe COPD } \\
\hline \multirow{2}{*}{ Breezhaler $^{\circ}$} & \multirow{2}{*}{10} & \multirow{2}{*}{$99.2(4.29)$} & $\begin{array}{l}\text { Breezhaler }{ }^{\circ} \text { vs. } \\
\text { Ellipta }\end{array}$ & 10 & 28.1 & $(23.94,32.32)$ & $<0.0001$ \\
\hline & & & $\begin{array}{l}\text { Breezhaler }{ }^{\circ} \text { vs. } \\
\text { HandiHaler }\end{array}$ & 10 & 47.9 & $(32.75,63.04)$ & $<0.0001$ \\
\hline Ellipta" & 10 & $71.0(4.20)$ & $\begin{array}{l}\text { Ellipta"vs. } \\
\text { HandiHaler" }\end{array}$ & 10 & 19.8 & $(6.36,33.18)$ & 0.0087 \\
\hline HandiHaler ${ }^{\circ}$ & 10 & $51.3(3.98)$ & & & & & \\
\hline
\end{tabular}


dry power inhalers (DPIs). Here, we present the comparison of the peak inspiratory flow (PIF) rates achieved by COPD patients, with varying degrees of airflow limitation, through three types of DPIs (Breezhaler ${ }^{\circledR}$, Ellipta ${ }^{\circledR}$ and HandiHaler ${ }^{\circledR}$ ). We also assessed the effect of severity of airflow limitation on PIF rates.

Methods This randomised, open-label, multicentre and crossover study recruited patients with moderate-to-very severe airflow limitation (GOLD 2014) aged $\geq 40$ years with a smoking history of $\geq 10$ pack years. No active drug or placebo was administered during the study. After training the patients on correct use, inhalation flow profiles of patients were recorded using pressure tapped inhalers attached to a pressure transducer. For each patient, the inhalation profile with the highest PIF rate, out of three replicate inhalations per device, was selected for analysis. The primary analysis was based on the per-protocol set comprising 93 patients who completed all three inhalations per device. A paired t-test was performed to compare PIF means between each combination of devices.

Results In total, 97 COPD patients were randomised, of whom 96 completed the study and 93 patients (per-protocol set) were included in the analysis. The highest mean PIF rate $(\mathrm{L} / \mathrm{min} \pm \mathrm{SE})$ was observed with the Breezhaler ${ }^{\circledR}(107.5 \pm 2.4)$, followed by the Ellipta ${ }^{\circledR}(80.0 \pm 2.2)$ and the HandiHaler ${ }^{\circledR}(53.6 \pm 2.1)$, in all patients (patients with moderate-to-very severe airflow limitation). The mean PIF rate $(\mathrm{L} / \mathrm{min})$ achieved via the Breezhaler ${ }^{\circledR}$ was higher vs the Ellipta $^{\circledR}$ (mean difference $[\Delta]=27.7$; $\mathrm{p}<0.0001)$ and also vs the HandiHaler ${ }^{\circledR}(\Delta=53.9$; $\mathrm{p}<0.0001)$. Also, when assessed by severity of airflow limitation, the Breezhaler ${ }^{\circledR}$ device exhibited significantly higher PIF rate vs the Ellipta ${ }^{\circledR}$ and vs the HandiHaler ${ }^{\circledR}$ (Table).

Conclusions COPD patients with varying degree of airflow limitation (moderate-to-very severe COPD) achieved the highest PIF rates via the Breezhaler ${ }^{\circledR}$ compared with the Ellipta ${ }^{\circledR}$ or the HandiHaler ${ }^{\circledR}$ inhaler.

\section{P289 DRUG PRODUCT PERFORMANCE THROUGH INHALER LIFE USING A LAMA/LABA COMBINATION IN A DRY POWDER INHALER}

J Plugge, U Basaldella, B Fyrnys, T Pieper. Sofotec GmbH, Bad Homburg, Germany

\subsection{6/thoraxinl-2016-209333.432}

Introduction Studies to test the delivered dose uniformity (DDU) and fine particle dose (FPD) delivery over inhaler life were performed with aclidinium bromide $400 \mu \mathrm{g} /$ formoterol fumarate dihydrate $12 \mu \mathrm{g}$ inhalation powder in the Genuair ${ }^{\mathrm{TM} *}$ inhaler.

Methods Developmental batches representative for commercial production were used. Samples were tested after release, and after 24 months of protected (pouched samples) stability storage at climatic zone II conditions. In-use tests were performed with unprotected samples over 2 months at climatic zone II conditions, both shortly after batch production ('fresh samples') and after protected pre-storage at climatic zone II conditions for 35 months. In addition, mass balance and mouthpiece deposition were assessed.

Results The studies show consistent performance through inhaler life from release up to 24 months of protected storage; all data were well inside the acceptance criteria applied during development. An example for the LABA active ingredient, formoterol fumarate dihydrate, is given in Figure 1. Furthermore, during inuse studies over 2 months, no impact of climatic zone II conditions on DDU and FPD could be detected, both for fresh samples and samples pre-stored for up to 35 months. No significant first delivered dose effect was seen; the slightly lower first doses are explained by mouthpiece deposition, as shown in Figure 1 for the LABA and the LAMA (aclidinium bromide) active ingredient. The mouthpiece deposition per actuation/dose ranged from $6.5 \%$ for actuation 1 to $1.3 \%$ for actuation 60 for the LABA active ingredient, and from $4.9 \%$ for actuation 1 to $1.2 \%$ for actuation 60 for the LAMA active ingredient.

Conclusions The drug product delivers consistent doses and fine particle doses through inhaler life. Mouthpiece deposition is determined to be low, showing no effect on the drug product performance.

*Registered trademark of AstraZeneca group of companies; for use within the USA as Pressair ${ }^{\circledR}$ and Genuair ${ }^{\mathrm{TM}}$ within all other licensed territories.

\section{P290 DRUG PRODUCT PERFORMANCE AFTER SIMULATED PATIENT HANDLING OF AN INHALATION POWDER USING A LAMA/LABA COMBINATION IN A DRY POWDER INHALER}

J Plugge, U Basaldella, B Fyrnys, T Pieper. Sofotec GmbH, Bad Homburg, Germany

\subsection{6/thoraxjnl-2016-209333.433}

Introduction Three studies simulating various patient handling effects were performed with aclidinium bromide $400 \mu \mathrm{g} /$ formoterol fumarate dihydrate $12 \mu \mathrm{g}$ inhalation powder in the Genuair $^{\mathrm{TM} *}$ inhaler.

Methods Developmental batches representative for commercial production were used. Samples were tested before and after cleaning of the mouthpiece with a dry tissue, after dosing at various orientations $\left(+45^{\circ} /-45^{\circ}\right)$ to the horizontal axis of the inhaler, or before and after dropping the inhaler in different orientations from a $1 \mathrm{~m}$ height. Test parameters included delivered dose uniformity (DDU) and fine particle dose (FPD).

Results All results for the LAMA (aclidinium bromide) and LABA (formoterol fumarate dihydrate) active ingredients were within the expected ranges and well inside the acceptance criteria applied during development (Figure 1). For aclidinium bromide, DDU mean values between 388 and $424 \mu \mathrm{g}$ (specification range $320-480 \mu \mathrm{g}$ ), and single values between 343 and $464 \mu \mathrm{g}$ (not specified) were observed. Mean FPD was tested within 156 and $175 \mu \mathrm{g}$ (specification range $120-200 \mu \mathrm{g}$ ), and FPD single values between 136 and $198 \mu \mathrm{g}$ (not specified). Results for the LABA active ingredient, formoterol fumarate dihydrate, were between 11.7 and $12.8 \mu \mathrm{g}$ for DDU mean values (specification range 9.6$14.4 \mu \mathrm{g}$ ) and between 9.6 and $13.8 \mu \mathrm{g}$ for DDU single values (not specified). Mean FPD was observed within 3.1 and $3.5 \mu \mathrm{g}$ (specification range $2.2-4.5 \mu \mathrm{g}$ ), and FPD single values between 2.6 and $4.0 \mu \mathrm{g}$ (not specified).

Conclusions The studies show that stable pharmaceutical quality can be guaranteed even if the device is used in different positions to the one explained in the patient information leaflet, after cleaning the mouthpiece, or after dropping the device in different orientations.

*Registered trademark of AstraZeneca group of companies; for use within the USA as Pressair ${ }^{\circledR}$ and Genuair ${ }^{\mathrm{TM}}$ within all other licensed territories. 